Research article Open Access

\title{
FGFR1 amplification in breast carcinomas: a chromogenic in situ hybridisation analysis
}

\author{
Somaia Elbauomy Elsheikh¹, Andrew R Green ${ }^{1}$, Maryou BK Lambros², Nicholas C Turner², \\ Matthew J Grainge ${ }^{3}$, Des Powe ${ }^{1}$, lan O Ellis ${ }^{1}$ and Jorge S Reis-Filho²
}

\author{
1Department of Histopathology, School of Molecular Medical Sciences, A Floor, West Block, Queen's Medical Centre, Nottingham University \\ Hospitals Trust and University of Nottingham, Nottingham, NG7 2UH, UK \\ 2The Breakthrough Breast Cancer Research Centre, Institute of Cancer Research, London, SW3 6JB, UK \\ ${ }^{3}$ Division of Epidemiology and Public Health, School of Community Health Sciences, Queen's Medical Centre, Nottingham University Hospitals Trust \\ and University of Nottingham, Nottingham, NG7 2UH, UK \\ Corresponding author: Jorge S Reis-Filho, jorgerf@icr.ac.uk
}

Received: 1 Dec 2006 Revisions requested: 9 Feb 2007 Revisions received: 12 Mar 2007 Accepted: 30 Mar 2007 Published: 30 Mar 2007

Breast Cancer Research 2007, 9:R23 (doi:10.1186/bcr1665)

This article is online at: http://breast-cancer-research.com/content/9/2/R23

(c) 2007 Elsheikh et al., licensee BioMed Central Ltd.

This is an open access article distributed under the terms of the Creative Commons Attribution License (http://creativecommons.org/licenses/by/2.0), which permits unrestricted use, distribution, and reproduction in any medium, provided the original work is properly cited.

\begin{abstract}
Background The amplicon on $8 p 11.2$ is reported to be found in up to $10 \%$ of breast carcinomas. It has been demonstrated recently that this amplicon has four separate cores. The second core encompasses important oncogene candidates, including the fibroblast growth factor receptor 1 (FGFR1) gene. Recent studies have demonstrated that specific FGFR1 amplification correlates with gene expression and that FGFR1 activity is required for the survival of a FGFR1 amplified breast cancer cell line.

Methods FGFR1 amplification was analysed in tissue microarrays comprising a cohort of 880 unselected breast tumours by means of chromogenic in situ hybridisation using inhouse-generated FGFR1-specific probes. Chromogenic in situ hybridisation signals were counted in a minimum 30 morphologically unequivocal neoplastic cells. Amplification was defined as $>5$ signals per nucleus in more than $50 \%$ of cancer cells or when large gene copy clusters were seen.
\end{abstract}

Results FGFR1 amplification was observed in $8.7 \%$ of the tumours and was significantly more prevalent in patients $>50$ years of age and in tumours that lacked HER2 expression. No association was found with other histological parameters. Survival analysis revealed FGFR1 amplification as an independent prognostic factor for overall survival in the whole cohort. Subgroup analysis demonstrated that the independent prognostic impact of FGFR1 amplification was only seen in patients with oestrogen-receptor-positive tumours, where FGFR1 amplification was the strongest independent predictor of poor outcome.

Conclusion Given that up to $8.7 \%$ of all breast cancers harbour FGFR1 amplification and that this amplification is an independent predictor of overall survival, further studies analysing the FGFR1 as a potential therapeutic target for breast cancer patients are warranted.

\section{Introduction}

Amplification of $8 p 11.2-p 12$ is reported to be found in up to $10-15 \%$ of all breast cancers [1-5]. For a long time it was believed that the fibroblast growth factor receptor 1 (FGFR1) would be the target oncogene of 8p11.2-p12 amplifications $[1,2,5,6]$. Recent studies, however, have called into question the role of FGFR1 as the 'amplicon driver', given that not all cell lines and breast cancers with 8p11.2-p12 amplification overexpressed the FGFR1 gene and that FGFR1 protein and mRNA expression was much more pervasive than gene ampli- fication [7-9]. Other oncogene candidates for the amplicon on 8p11.2-p12 have been put forward, including zinc finger protein 703 (FLJ14299), SPFH domain family member 2 (SPFH2, also known as C8orf2), subunit of RNA polymerase III transcription initiation factor (BRF2) and RAB11 family interacting protein 1 (RAB11FIP1) [7].

Gelsi-Boyer and colleagues [3] have demonstrated more recently that the 8p11.2-p12 amplicon is much more complex than previously anticipated and that it comprises at least four

$\overline{\mathrm{CISH}}=$ chromogenic in situ hybridisation; $\mathrm{CK}=$ cytokeratin; $\mathrm{ER}=$ oestrogen receptor; FGFR1 = fibroblast growth factor receptor $1 ; \mathrm{NPI}=\mathrm{Notting}-$ ham Prognostic Index. 
independent cores, which can be amplified independently [3]. While FLJ14299, SPFH2, proline synthetase cotranscribed homologue (PROSC), BRF2, and RAB11FIP1 were associated with core $A 1$, golgin subfamily a 7 (GOLGA7) was correlated with $A 3$, and MYST histone acetyltransferase 3 (MYST3) and miR172-resistant version of AP2 (AP2M3) were associated with $\mathrm{A} 4$. The genes whose expression correlated with amplification of core A2 included LSM1 homologue, U6 small nuclear RNA associated ( $L S M 1$, also known as cancer-associated Sm-like (CASM)), DDHD domain containing 2 (DDHD2), phosphatidic acid phosphatase type 2 domain containing 1B (HTPAP), Wolf-Hirschhorn syndrome candidate 1like 1 (WHSC1L1), TM2 and FGFR1 [3]. Interestingly, amplification of core 2, but not the other cores, was associated with shorter metastasis-free survival [3].

FGFR1 gene encodes a tyrosine kinase receptor that is part of the fibroblast growth factor and growth factor receptors family [10-12]. FGFR1 expression has been shown to play pivotal roles in mammary development and breast cancer tumourigenesis [12,13]. Activation of FGFR1 in a transgenic mouse model resulted in increased luminal cell proliferation, activation of mitogen-activated protein kinase and Akt, lateral budding and, eventually, alveolar hyperplasia and invasive lesions $[11,12]$. In addition, we have recently demonstrated that when core 2 of the 8p11.2-p12 is amplified, the FGFR1 gene shows increased levels of mRNA and protein expression [14]. Furthermore, we have also determined in vitro that FGFR1 signalling is paramount for the survival of a FGFR1 amplified breast cancer cell line [14].

The prognostic impact of FGFR1 amplification in breast cancer still remains unclear. In previous studies analysing FGFR1 amplification by means of Southern blot or fluorescent in situ hybridisation, conflicting results were observed: while FGFR1 amplification proved to be associated with positivity for oestrogen receptor (ER) in one study [1], Prentice and colleagues found no association between FGFR1 amplification and clinicopathological parameters or patients' survival [4]. More recently, using probes for both RAB11FIP1 and FGFR1, Letessier and colleagues [15] demonstrated that cases with 8 p12 amplification have a significantly shorter metastasis-free survival [15].

Chromogenic in situ hybridisation ( $\mathrm{CISH}$ ) is a technique that allows for a concurrent analysis of the gene copy number and morphological features of the cells [16-21]. Although results obtained with $\mathrm{CISH}$ show an excellent concordance with those obtained with fluorescent in situ hybridisation [21], $\mathrm{CISH}$ has proven useful for high-throughput copy number assessment, given that it can be easily applied to tissue microarrays and the analysis can be performed with a conventional light microscope [16-21]. No studies analysing FGFR1 amplification, as defined by $\mathrm{CISH}$, in a large cohort of breast cancer patients have so far been performed. Using a previously described method [18], inhouse probes specific for FGFR1 were generated and we set out to characterise the prevalence of FGFR1 amplification in a large community-based cohort of breast cancers and its correlations with traditional clinicopathological features, immunohistochemical markers, and disease-free and overall survival.

\section{Materials and methods Tissue microarrays}

The tissue microarrays comprised a cohort of 880 unselected breast tumours from patients presenting between 1986 and 1998 entered into the Nottingham Tenovus Primary Breast Carcinoma Series (447 invasive ductal carcinomas of no special type, 183 tubular mixed carcinomas, 25 medullary carcinomas, 84 lobular carcinomas, 28 tubular carcinomas, eight mucinous carcinomas, six cribriform carcinomas, four papillary carcinomas, 29 mixed no special type and lobular carcinomas, 23 mixed no special type and special-type carcinomas, and six miscellaneous tumours - histological type not available in 37 cases). Patient management was based on tumour characteristics by the Nottingham Prognostic Index (NPI) and hormone receptor status. Patients with an NPI score $\leq 3.4$ received no adjuvant therapy, and those with a NPI score $>3.4$ received tamoxifen if they were ER-positive ( \pm Zoladex if premenopausal) or received classical cyclophosphamide, methotrexate and 5-fluorouracil if they were ER-negative and fit enough to tolerate chemotherapy [22]. Full details of the characterisation of the tissue microarray and the cohort of patients are summarised in Table 1. Tumours were graded according to a modified Bloom-Richardson scoring system [23] and size was categorised according to the TNM staging criteria [24]. The NPI was calculated as previously described [25].

Survival data including the survival time and the disease-free interval were maintained on a prospective basis. Disease-free survival was defined as the interval (in months) from the date of the primary surgical treatment to the first locoregional (including invasive malignancy and ductal carcinoma in situ) or distant recurrence. Overall survival was taken as the time (in months) from the date of the primary surgical treatment to the time of death from breast cancer. The immunohistochemical methods and the results on ER, progesterone receptor, cytokeratin (CK) 7/8, CK 18, CK 19, CK 5/6, CK 14, HER2 and epidermal growth factor receptor have been previously described $[26,27]$.

This study was approved by the Nottingham Research Ethics Committee 2 under the title 'Development of a molecular genetic classification of breast cancer'.

\section{Chromogenic in situ hybridisation}

CISH for FGFR1 gene amplification was performed on 2- $\mu \mathrm{m}$ thick tissue microarray sections mounted on polylysine-coated slides, using an inhouse-generated probe as previously described [18]. This probe comprises three bacterial artificial 
Table 1

\begin{tabular}{lll}
$\begin{array}{l}\text { Frequencies and percentages of tumour grades, size, lymph node stage, distant metastasis and patient age in the tissue } \\
\text { microarrays }\end{array}$ & Percentage \\
\hline \multicolumn{1}{l}{ Frequency } & \\
\hline Grade & 191 & 22.7 \\
1 & 273 & 32.4 \\
2 & 378 & 44.9 \\
3 & 561 & \\
Lymph node stage & 203 & 66.7 \\
0 & 77 & 24.1 \\
N1 & & 9.2 \\
N2 & 301 & 35.7 \\
Tumour size & 543 & 64.3 \\
$\leq 1.5$ cm & & 85.0 \\
$>1.5$ cm & 717 & 15.0 \\
Distance metastasis & 127 & 35.4 \\
M0 & & 64.6 \\
M1 & 299 & \\
Age & 545 & \\
$\leq 50$ years & & \\
$>50$ years & &
\end{tabular}

chromosome contigs (RP11-350N15, RP11-148D21 and RP11-359P11), which map to the region 38.3-38.6 Mb on chromosome 8p12-p11.23 and encompasses the FGFR1 and part of WHSC1L1. Heat pretreatment of deparaffinised sections consisted of incubation for 15 minutes at $98^{\circ} \mathrm{C}$ in $\mathrm{CISH}$ pretreatment buffer (SPOT-light tissue pretreatment kit; Zymed (South San Francisco, CA, USA) and digestion with pepsin for 5.5 minutes at room temperature according to the manufacturer's instructions. Slides were hybridised and developed as previously described. An appropriate FGFR1 geneamplified breast carcinoma control was included in the slide run.

$\mathrm{CISH}$ experiments were analysed by two of the authors (SEE and ARG) on a multiheaded microscope. Only unequivocal signals were counted. Signals were evaluated at $400 \times$ magnification and $630 \times$ magnification, and 30 morphologically unequivocal neoplastic cells in each core were assessed for the presence of the FGFR1 gene signals. Amplification was defined as those cases where $>50 \%$ of the neoplastic cells harboured either $>5$ copies of the gene or large gene clusters. $\mathrm{CISH}$ analysis was performed with observers blinded to clinicopathological parameters, patients' survival and results of the immunohistochemical analysis.

\section{Statistical analysis}

Statistical analysis was performed using SPSS 13.0 statistical software (SPSS INC., Chicago, IL, USA). Median follow-up was defined as the median follow-up for those patients still alive and disease free at the latest hospital visit. Cutoff values for the different biomarkers included in this study were chosen before statistical analysis. Standard cutoff values were used for established prognostic factors and were the same as for previously published patient series [27]. All factors were used as dichotomous covariates in the statistical analysis with the exception of grade and the NPI, which were categorised into three groups.

The associations between the FGFR1 amplification and clinicopathological parameters were evaluated by the chi-square test. Confidence intervals of $95 \%$ were adopted. A two-sided $P$ value $<0.05$ was considered statistically significant. Survival curves were calculated by the Kaplan-Meier method. Differences in survival on the basis of FGFR1 amplification were estimated using the log-rank test. Multivariate Cox regression analysis was used to evaluate any independent prognostic effect of the variable on disease-free survival and the overall survival, which was adjusted by such well-known prognostic factors as tumour grade, lymph node stage, tumour size, and ER status. 
Figure 1

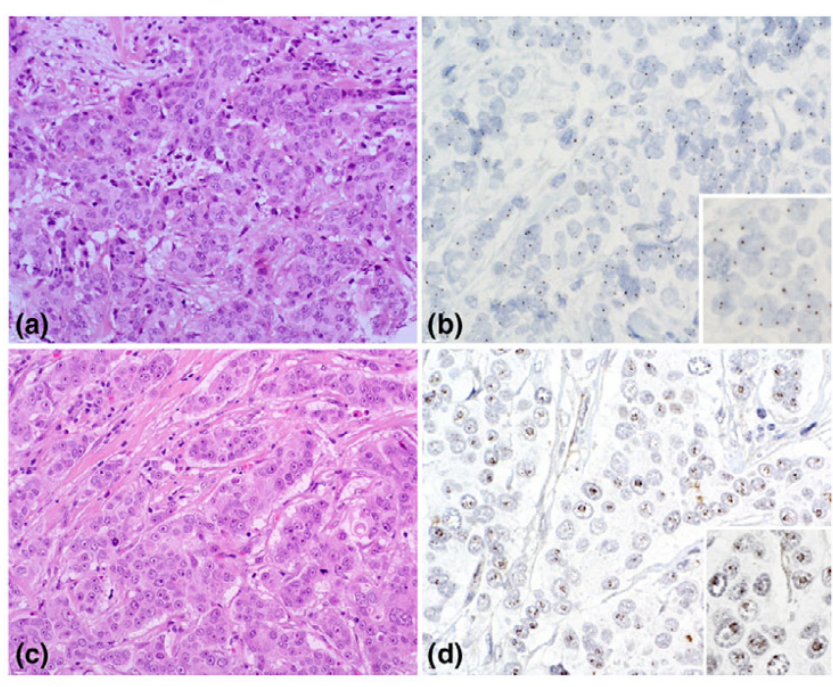

FGFR1 gene amplification in breast cancer. (a) Grade 3 invasive ductal carcinoma (haematoxylin and eosin; original magnification $\times 200$ ) with (b) one or two copies of FGFR1 (original magnification $\times 400$; inset: $\times$ 630). (c) Grade 3 invasive ductal carcinoma (haematoxylin and eosin; original magnification $\times 200$ ) harbouring (d) FGFR1 gene amplification (original magnification $\times 400$; inset: $\times 630$ ).

\section{Results}

After excluding the uninformative tissue microarray cores, results on FGFR1 amplification were available for 496 tumours. Forty-three tumours (8.7\%) showed either $>5$ signals or large gene clusters in $>50 \%$ of neoplastic cells (Figure 1).

Complete clinical follow-up information was available for 478 patients for whom FGFR1 $\mathrm{CISH}$ results were optimal. The median follow-up period was 58 months (range 1-192 months). During this period, a total of 73 (14.7\%) patients died from breast cancer. Of all cases, 116 (24.3\%) cases were grade 1, $141(29.5 \%)$ cases were grade 2, and 221 $(46.2 \%)$ were grade 3 . From the available data, $153(32.2 \%)$ of the patients had lymph-node-positive disease, 130 (27.8\%) had positive vascular invasion, and $311(65.1 \%)$ had tumour size $\geq 1.5 \mathrm{~cm}$. Recurrence occurred in 147 cases $(30.8 \%)$, and distant metastases developed in 84 cases (17.6\%). A total of $149 / 496$ (30\%) patients received tamoxifen, 5/496 (1\%) received tamoxifen and Zoladex, and 309/496 (62.3\%) received no endocrine treatment. There was no significant difference between the disease-free interval $(P=0.761)$ or overall survival $(P=0.225)$ between those patients that received hormone therapy compared with those patients that did not. A total of $48 / 496(9.7 \%)$ patients received chemotherapy.

Table 2 summarises the associations between FGFR1 gene amplification and key prognostic and outcome parameters. In brief, patients with positive FGFR1 amplification were significantly more likely to be older than 50 years of age $(P<0.05)$ and to develop distant metastasis $(P<0.05)$. FGFR1 amplification showed an inverse correlation with HER2 overexpres- sion. A trend for lack of progesterone receptor expression and negativity for basal markers, as defined by Abd El-Rehim and colleagues [27], was also observed. No associations were found between FGFR1 amplification and the grade, lymphnode stage, NPI, expression of ER, low-molecular-weight cytokeratins (CK 7/8, CK 8 and CK 19) or high-molecularweight cytokeratins (CK 5/6 and CK 14) or basal-like phenotype as defined by Nielsen and colleagues [28] (that is, ERnegative and HER2-negative, CK 5/6 and/or epidermal growth factor receptor-positive).

Kaplan-Meier survival analysis revealed an association between FGFR1 amplification and a shorter overall survival $(P$ $=0.01$, log-rank test) (Figure 2a). A trend for a shorter disease-free survival and FGFR1 amplification was found $(P<$ 0.07, log-rank test) (Figure 2b). On multivariate Cox hazard analysis adjusted for tumour grade, size and lymph node status, for ER status, and for FGFR1 amplification, it was found that the FGFR1 amplification was a significant predictor of poor overall survival independent of the other known prognostic parameters $(P<0.04)$ (Table 3$)$.

Subgroup analysis revealed that FGFR1 amplification was an independent prognostic factor for disease-free survival and overall survival only in ER-positive tumours (Figure 2c,d and Table 4). The association between FGFR1 amplification and poor outcome was maintained in the group of patients that received endocrine therapy (Figure 2e,f). FGFR1 amplification in ER-positive disease was the strongest independent risk factor for poor disease-free survival and overall survival, with a greater hazard ratio than high histological grade. Patients with FGFR1 amplification in the ER-positive group were significantly more likely to develop distant metastases and were associated with a lack of progesterone receptor expression $(P$ $<0.05$ ) (Table 5). In the cohort of ER-positive tumours, no further associations between FGFR1 amplification and other clinicopathological parameters were found. No associations were seen between FGFR1 amplification and survival of patients with ER-negative breast cancers.

\section{Discussion}

In recent years it has been demonstrated that $\mathrm{CISH}$ is a useful technique to determine gene copy numbers and gene amplification on formalin-fixed, paraffin-embedded tissue sections [16-21]. Unlike fluorescent in situ hybridisation, $\mathrm{CISH}$ allows a direct comparison between morphological features of neoplastic cells and the presence of gene amplification [1621]. Furthermore, $\mathrm{CISH}$ analysis is relatively quick; in the present study, the whole analysis of FGFR1 amplification in a cohort of 880 patients took 2 weeks and, although only one tissue microarray core per tumour was analysed, 56\% cases rendered optimal results.

We demonstrate in the present study that FGFR1 amplification is found in $8.7 \%$ of breast cancers, which is in agreement 
Table 2

\begin{tabular}{|c|c|c|c|}
\hline Parameter & Number of samples & Positive FGFR1 amplification number (\%) & $P$ value \\
\hline Age & 478 & & 0.027 \\
\hline$<50$ years & 152 & $7(4.6)$ & \\
\hline$\geq 50$ years & 346 & $35(10.1)$ & \\
\hline Grade & 478 & & Not significant \\
\hline 1 & 116 & $10(8.6)$ & \\
\hline 2 & 141 & $12(8.5)$ & \\
\hline 3 & 221 & $20(9.0)$ & \\
\hline Size & 478 & & Not significant \\
\hline$\geq 1.5 \mathrm{~cm}$ & 311 & $30(9.6)$ & \\
\hline$>1.5 \mathrm{~cm}$ & 167 & $12(7.2)$ & \\
\hline Lymph node stage & 475 & & Not significant \\
\hline No & 322 & $28(8.7)$ & \\
\hline $\mathrm{N} 1$ & 110 & $9(8.2)$ & \\
\hline N2 & 43 & $4(9.3)$ & \\
\hline Nottingham Prognostic Index & 475 & & Not significant \\
\hline Good & 175 & $14(8.0)$ & \\
\hline Moderate & 239 & $21(8.8)$ & \\
\hline Poor & 61 & $6(9.8)$ & \\
\hline Distant metastasis & 478 & & 0.050 \\
\hline No & 394 & $30(7.6)$ & \\
\hline Definite & 84 & $12(14.3)$ & \\
\hline Vascular invasion & 467 & & Not significant \\
\hline No & 337 & $27(8.0)$ & \\
\hline Yes & 130 & $14(10.8)$ & \\
\hline Oestrogen receptor & 453 & & Not significant \\
\hline Negative & 140 & $10(7.1)$ & \\
\hline Positive & 313 & $27(8.6)$ & \\
\hline Progesterone receptor & 449 & & 0.084 \\
\hline Negative & 206 & $22(10.7)$ & \\
\hline Positive & 243 & $15(6.2)$ & \\
\hline
\end{tabular}


Breast Cancer Research Vol 9 No 2 Elsheikh et al.

Table 2 (Continued)

Correlation between FGFR1 gene amplification and the clinicopathological variables

\begin{tabular}{|c|c|c|c|}
\hline HER2 & 445 & & 0.043 \\
\hline Negative & 259 & $28(10.8)$ & \\
\hline Positive & 186 & $10(5.4)$ & \\
\hline Androgen receptor & 415 & & Not significant \\
\hline Negative & 188 & $18(9.6)$ & \\
\hline Positive & 227 & $13(5.7)$ & \\
\hline Cytokeratin 7/8 & 467 & & Not significant \\
\hline Negative & 167 & $17(10.2)$ & \\
\hline Positive & 300 & $24(8.0)$ & \\
\hline Cytokeratin 18 & 396 & & Not significant \\
\hline Negative & 116 & $7(6.0)$ & \\
\hline Positive & 280 & $23(8.2)$ & \\
\hline Cytokeratin 19 & 464 & & Not significant \\
\hline Negative & 95 & $10(10.5)$ & \\
\hline Positive & 369 & $30(8.1)$ & \\
\hline Cytokeratin $5 / 6$ & 465 & & Not significant \\
\hline Negative & 350 & $34(9.7)$ & \\
\hline Positive & 115 & $6(5.2)$ & \\
\hline Cytokeratin 14 & 458 & & Not significant \\
\hline Negative & 357 & $33(9.2)$ & \\
\hline Positive & 101 & $6(5.9)$ & \\
\hline Epidermal growth factor receptor & 351 & & Not significant \\
\hline Negative & 292 & $26(8.9)$ & \\
\hline Positive & 59 & $3(5.1)$ & \\
\hline Basal markers [27] & 455 & & Not significant \\
\hline Negative & 311 & $31(10.0)$ & \\
\hline Positive & 144 & $8(5.6)$ & \\
\hline Nielsen groups [28] & 396 & & Not significant \\
\hline HER2 & 39 & $3(7.7)$ & \\
\hline Basal-like & 55 & $3(5.5)$ & \\
\hline Luminal & 302 & $26(8.6)$ & \\
\hline
\end{tabular}

Page 6 of 12

(page number not for citation purposes) 
(a)

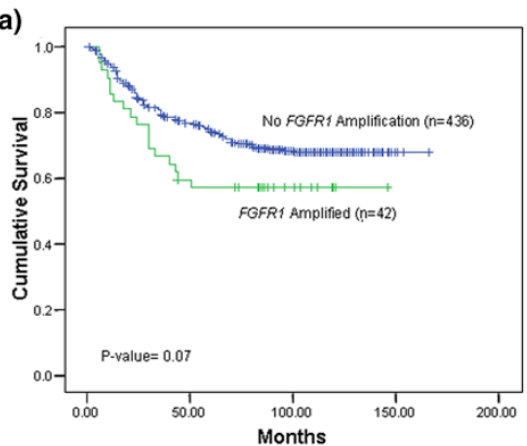

(c)

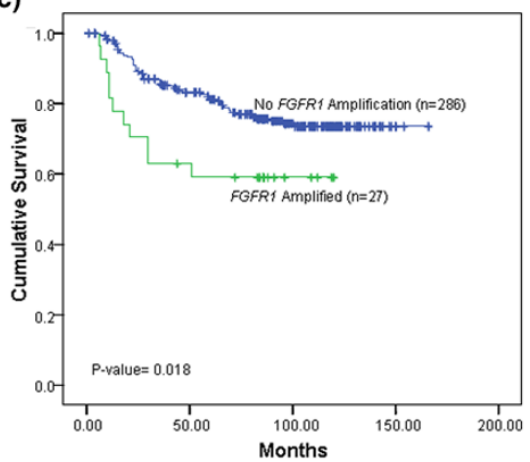

(e)

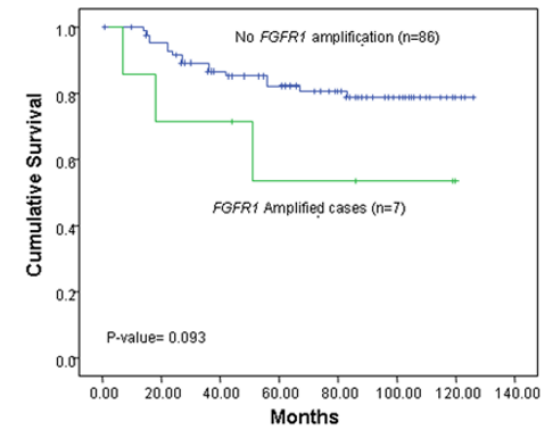

(b)

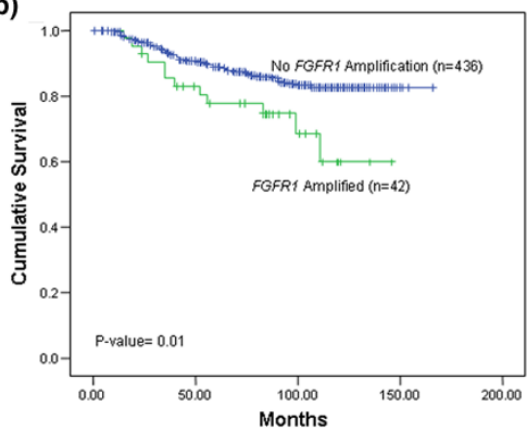

(d)

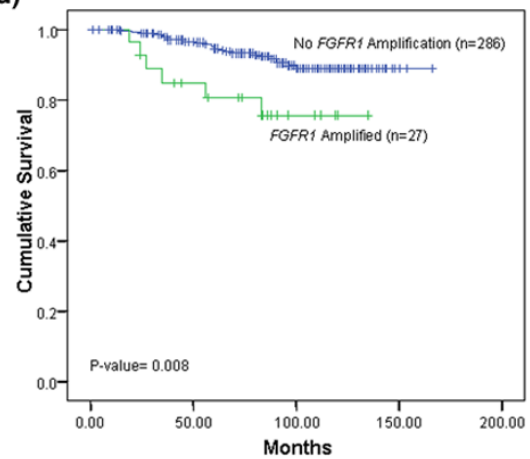

(f)

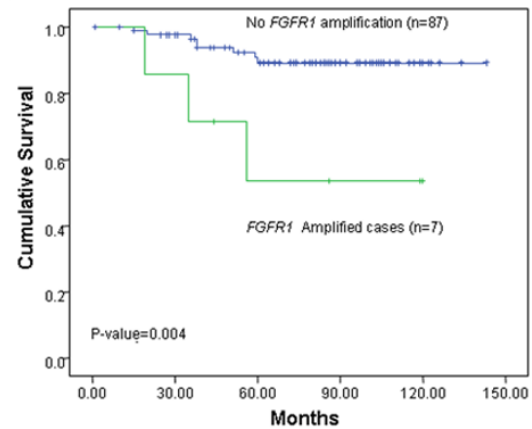

Univariate analysis of the prognostic impact of FGFR1 gene amplification overexpression on disease-free survival and overall survival. (a) Whole cohort, disease-free survival. (b) Whole cohort, overall survival. (c) Oestrogen-receptor-positive cases, disease-free survival. (d) Oestrogen-receptor-positive cases, overall survival. (e) Oestrogen-receptor-positive patients that received endocrine therapy, disease-free survival. (f) Oestrogenreceptor-positive patients that received endocrine therapy, overall survival.

with previous studies [1-4,29]. Unlike previous studies where FGFR1 amplification was determined by Southern blot analysis [1], our results and those obtained with other in situ methods $[3,4,15]$ did not show any correlation between FGFR1 amplification and low histological grade or positivity for ER. On the other hand, our results demonstrate that FGFR1 amplification is an independent predictor of poor outcome, especially for patients with ER-positive breast cancers. Interestingly, the impact of FGFR1 amplification was stronger on overall survival than disease-free survival (that is, higher hazard ratios on multivariate analysis). This may stem from the fact that locoregional recurrences were included as events for disease-free survival analysis, and that overall survival considered only breast-cancer-related deaths as events. Alternatively, this may reflect the association between FGFR1 amplification and the development of distant metastasis $(P=0.05)$ or a shorter survival after the first distant recurrence event.

Our group [14] and others [3] have demonstrated that when FGFR1 is specifically amplified (that is, amplification of core A2 of the 8p11.2-p12 amplicon) it is also overexpressed, and that FGFR1 signalling is important for the survival of a cell line that harbours FGFR1 amplification and high-level gene expression $[14,30]$. Taken together, these results suggest 
Table 3

Cox proportional hazards analysis for predictors of overall survival: effects of tumour grade, size, lymph node stage, oestrogen receptor status and FGFR1 amplification

\begin{tabular}{llll}
\hline Variable & Hazard ratio & $95 \%$ confidence interval & $P$ value \\
\hline Grade $^{\mathrm{a}}$ & 2.13 & $1.32-3.44$ & 0.002 \\
Tumour size $\geq 1.5 \mathrm{~cm}^{\mathrm{b}}$ & 2.17 & $1.06-4.44$ & 0.034 \\
Positive lymph node stage & 3.52 & $2.17-5.72$ & $<0.001$ \\
Positive oestrogen receptor status & 0.44 & $0.26-0.74$ & 0.002 \\
FGFR1 amplification & 2.00 & $1.02-3.92$ & 0.043
\end{tabular}

aFitted as a linear term; that is, an increase in risk for change in grade of one unit.

bCompared with tumour size $<1.5 \mathrm{~cm}$.

that, in a significant proportion of cases with core A2 amplification, FGFR1 may be the actual amplicon driver [6]. We could not correlate FGFR1 amplification with expression in this study, as it was not possible to optimise antibodies for FGFR1 immunohistochemical analysis on tissue microarrays due to the highly fixation-dependent nature of the commercially available antibodies (data not shown).

The FGFR1 gene encodes a tyrosine kinase receptor that has been shown to play an important role in mammary gland development $[12,13,31]$. Previous studies have shown in vitro and in vivo that FGFR1 overexpression has oncogenic properties [10,12-14,31]. Furthermore, FGFR1 has been implicated in the tumourigenesis of haematological malignancies, where it is frequently involved in balanced chromosomal translocations, including cases of chronic myeloid leukaemia (BCR-FGFR1 fusion) and the 8p11 myeloproliferative syndrome/stem cell leukaemia-lymphoma syndrome, which is characterised by myeloid hyperplasia and non-Hodgkin's lymphoma with chromosomal translocations fusing several genes, the most common being a fusion between ZNF198 and FGFR1 [32]. In preclinical models, the PKC412 tyrosine kinase inhibitor has been shown to successfully inhibit the growth of proliferation of ZNF198-FGFR1-transformed Ba/F3 cells and to prolong the survival of animals with a ZNF198-FGFR1-induced stem cell leukaemia-lymphoma syndrome [33]. Targeting FGFR1 signalling with RNA interference or with the SU5402 FGFR1 tyrosine kinase inhibitor has been shown to decrease cell survival in a breast cancer cell line with FGFR1 amplification [14].

\section{Conclusion}

Taken together, our results demonstrate that FGFR1 amplification is found in $8.7 \%$ of breast cancers and is an independent predictor of outcome. Although large studies correlating FGFR1 amplification with mRNA and protein expression are

Table 4

Cox proportional hazards analysis for predictors of disease-free and overall survival: effects of tumour grade, size, lymph node stage, oestrogen receptor (ER) status and FGFR1 status in ER-positive and ER-negative tumours

\begin{tabular}{|c|c|c|c|c|c|c|}
\hline \multirow[t]{2}{*}{ Variable } & \multicolumn{3}{|c|}{ ER-positive tumours } & \multicolumn{3}{|c|}{ ER-negative tumours } \\
\hline & Hazard ratio & $95 \%$ confidence interval & $P$ value & Hazard ratio & $95 \%$ confidence interval & $P$ value \\
\hline \multicolumn{7}{|l|}{ Disease-free interval } \\
\hline Grade $^{a}$ & 1.387 & $1.027-1.874$ & 0.033 & 1.001 & $0.637-1.574$ & 0.996 \\
\hline Tumour size $\geq 1.5 \mathrm{~cm}^{\mathrm{b}}$ & 1.551 & $0.926-2.595$ & 0.095 & 2.348 & $1.092-5.052$ & 0.029 \\
\hline Positive lymph node stage & 1.407 & $0.879-2.252$ & 0.155 & 2.597 & $1.563-4.315$ & 0.000 \\
\hline FGFR1 amplification & 2.250 & $1.184-4.274$ & 0.013 & 1.104 & $0.440-2.774$ & 0.833 \\
\hline \multicolumn{7}{|l|}{ Overall survival } \\
\hline Grade $^{a}$ & 2.600 & $1.471-4.594$ & 0.001 & 1.673 & $0.731-3.829$ & 0.223 \\
\hline Tumour size $\geq 1.5 \mathrm{~cm}^{b}$ & 2.124 & $0.792-5.697$ & 0.134 & 2.594 & $0.911-7.387$ & 0.074 \\
\hline Positive lymph node stage & 1.973 & $0.953-4.083$ & 0.067 & 5.124 & $2.646-9.924$ & 0.000 \\
\hline FGFR1 amplification & 3.389 & $1.374-8.358$ & 0.008 & 1.278 & $0.450-3.624$ & 0.645 \\
\hline
\end{tabular}

aFitted as a linear term; that is, an increase in risk for change in grade of one unit.

bCompared with tumour size $<1.5 \mathrm{~cm}$. 


\section{Table 5}

Correlation between FGFR1 gene amplification and the clinicopathological variables in the oestrogen-receptor-positive group

\begin{tabular}{|c|c|c|c|}
\hline Parameter & Number of samples & Positive FGFR1 amplification number (\%) & $P$ value \\
\hline Age & 313 & & Not significant \\
\hline$<50$ years & 95 & $6(6.3)$ & \\
\hline$\geq 50$ years & 218 & $21(9.6)$ & \\
\hline Grade & 313 & & Not significant \\
\hline 1 & 99 & $8(8.1)$ & \\
\hline 2 & 120 & $10(8.3)$ & \\
\hline 3 & 94 & $9(9.6)$ & \\
\hline Size & 313 & & Not significant \\
\hline$\geq 1.5 \mathrm{~cm}$ & 188 & $19(10.1)$ & \\
\hline$<1.5 \mathrm{~cm}$ & 125 & $8(6.4)$ & \\
\hline Lymph node stage & 311 & & Not significant \\
\hline No & 214 & $19(8.9)$ & \\
\hline N1 & 74 & $6(8.2)$ & \\
\hline N2 & 23 & $2(9.3)$ & \\
\hline Nottingham Prognostic Index & 311 & & Not significant \\
\hline Good & 148 & $11(7.4)$ & \\
\hline Moderate & 133 & $14(10.5)$ & \\
\hline Poor & 30 & $2(6.7)$ & \\
\hline Distant metastasis & 313 & & 0.032 \\
\hline No & 273 & $20(7.3)$ & \\
\hline Definite & 40 & $7(17.5)$ & \\
\hline Vascular invasion & 303 & & Not significant \\
\hline No & 224 & $18(8)$ & \\
\hline Yes & 79 & $8(10.1)$ & \\
\hline Progesterone receptor & 305 & & 0.05 \\
\hline Negative & 80 & $11(13.8)$ & \\
\hline Positive & 225 & $15(6.7)$ & \\
\hline
\end{tabular}


Breast Cancer Research Vol 9 No 2 Elsheikh et al.

Table 5 (Continued)

Correlation between FGFR1 gene amplification and the clinicopathological variables in the oestrogen-receptor-positive group

\begin{tabular}{|c|c|c|c|}
\hline HER2 & 299 & & 0.063 \\
\hline Negative & 179 & $20(11.2)$ & \\
\hline Positive & 120 & $6(5.0)$ & \\
\hline Androgen receptor & 283 & & 0.08 \\
\hline Negative & 90 & $11(12.2)$ & \\
\hline Positive & 193 & $12(6.2)$ & \\
\hline Cytokeratin 7/8 & 310 & & Not significant \\
\hline Negative & 73 & $8(11)$ & \\
\hline Positive & 237 & $19(8.0)$ & \\
\hline Cytokeratin 18 & 269 & & Not significant \\
\hline Negative & 46 & $1(2.2)$ & \\
\hline Positive & 223 & $21(9.4)$ & \\
\hline Cytokeratin 19 & 308 & & Not significant \\
\hline Negative & 33 & $4(12.1)$ & \\
\hline Positive & 275 & $22(8.0)$ & \\
\hline Cytokeratin $5 / 6$ & 306 & & Not significant \\
\hline Negative & 261 & $24(9.2)$ & \\
\hline Positive & 45 & $2(4.4)$ & \\
\hline Cytokeratin 14 & 299 & & Not significant \\
\hline Negative & 252 & $23(9.1)$ & \\
\hline Positive & 47 & $2(4.3)$ & \\
\hline Epidermal growth factor receptor & 242 & & Not significant \\
\hline Negative & 209 & $19(9.1)$ & \\
\hline Positive & 33 & $2(6.1)$ & \\
\hline Basal markers [27] & 297 & & Not significant \\
\hline Negative & 234 & $22(9.4)$ & \\
\hline Positive & 63 & $3(4.8)$ & \\
\hline
\end{tabular}


still needed, the functional data demonstrating that FGFR1 signalling is required for the survival of breast cancer cells harbouring FGFR1 amplification [14], the relatively high prevalence of FGFR1 amplification in breast cancer and the independent prognostic information provided by FGFR1 amplification status support the idea that this gene may be a useful therapeutic target for a subgroup of breast cancer patients with FGFR1 gene amplification [14].

\section{Competing interests}

The authors declare that they have no competing interests.

\section{Authors' contributions}

SEE and ARG analysed the CISH experiments, performed in part the statistical analysis and helped to draft the manuscript. MBKL performed the laboratory work for FGFR1 inhouse probe generation and hybridisation to tissue microarrays. NCT participated in the study design, the interpretation of the results and statistical analysis. MJG supervised and reviewed the statistical analysis. DP participated in the interpretation of the results. IOE participated in the study design, data analysis and helped to draft the manuscript. JSR-F conceived the study, designed the probes for FGFR1, supervised the statistical analysis and drafted the manuscript. All authors read and approved the final manuscript.

\section{Acknowledgements}

This study was supported in part by Breakthrough Breast Cancer. The authors are grateful to Professor Alan Ashworth for his invaluable comments.

\section{References}

1. Courjal F, Cuny M, Simony-Lafontaine J, Louason G, Speiser P, Zeillinger R, Rodriguez $C$, Theillet C: Mapping of DNA amplifications at 15 chromosomal localizations in 1875 breast tumors: definition of phenotypic groups. Cancer Res 1997, 57:4360-4367.

2. Cuny M, Kramar A, Courjal F, Johannsdottir V, lacopetta B, Fontaine $\mathrm{H}$, Grenier J, Culine S, Theillet C: Relating genotype and phenotype in breast cancer: an analysis of the prognostic significance of amplification at eight different genes or loci and of p53 mutations. Cancer Res 2000, 60:1077-1083.

3. Gelsi-Boyer V, Orsetti B, Cervera N, Finetti P, Sircoulomb F, Rouge C, Lasorsa L, Letessier A, Ginestier C, Monville F, et al:: Comprehensive profiling of 8p11-12 amplification in breast cancer. Mol Cancer Res 2005, 3:655-667.

4. Prentice LM, Shadeo A, Lestou VS, Miller MA, deLeeuw RJ, Makretsov N, Turbin D, Brown LA, Macpherson N, Yorida E, et al.: NRG1 gene rearrangements in clinical breast cancer: identification of an adjacent novel amplicon associated with poor prognosis. Oncogene 2005, 24:7281-7289.

5. Theillet $\mathrm{C}$, Adelaide J, Louason G, Bonnet-Dorion F, Jacquemier J, Adnane J, Longy M, Katsaros D, Sismondi P, Gaudray P, et al:: FGFRI and PLAT genes and DNA amplification at 8p12 in breast and ovarian cancers. Genes Chromosomes Cancer 1993, 7:219-226.

6. Ugolini F, Adelaide J, Charafe-Jauffret $E$, Nguyen $C$, Jacquemier J, Jordan B, Birnbaum D, Pebusque MJ: Differential expression assay of chromosome arm $8 p$ genes identifies frizzled-related (FRP1/FRZB) and fibroblast growth factor receptor 1 (FGFR1) as candidate breast cancer genes. Oncogene 1999, 18:1903-1910.

7. Garcia MJ, Pole JC, Chin SF, Teschendorff A, Naderi A, Ozdag H, Vias M, Kranjac T, Subkhankulova T, Paish C, et al:: A 1 Mb mini- mal amplicon at 8p11-12 in breast cancer identifies new candidate oncogenes. Oncogene 2005, 24:5235-5245.

8. Ray ME, Yang ZQ, Albertson D, Kleer CG, Washburn JG, Macoska $J A$, Ethier SP: Genomic and expression analysis of the 8p11-12 amplicon in human breast cancer cell lines. Cancer Res 2004 64:40-47.

9. Yang ZQ, Albertson D, Ethier SP: Genomic organization of the 8p11-p12 amplicon in three breast cancer cell lines. Cancer Genet Cytogenet 2004, 155:57-62.

10. Eswarakumar VP, Lax I, Schlessinger J: Cellular signaling by fibroblast growth factor receptors. Cytokine Growth Factor Rev 2005, 16:139-149.

11. Welm BE, Freeman KW, Chen M, Contreras A, Spencer DM, Rosen JM: Inducible dimerization of FGFR1: development of a mouse model to analyze progressive transformation of the mammary gland. J Cell Biol 2002, 157:703-714.

12. Xian W, Schwertfeger KL, Vargo-Gogola T, Rosen JM: Pleiotropic effects of FGFR1 on cell proliferation, survival, and migration in a 3D mammary epithelial cell model. J Cell Biol 2005, 171:663-673.

13. Suyama K, Shapiro I, Guttman M, Hazan RB: A signaling pathway leading to metastasis is controlled by $\mathrm{N}$-cadherin and the FGF receptor. Cancer Cell 2002, 2:301-314.

14. Reis-Filho JS, Simpson PT, Turner NC, Lambros MB, Jones C Mackay A, Grigoriadis A, Sarrio D, Savage K, Dexter T, et al:: FGFR1 emerges as a potential therapeutic target for lobular breast carcinomas. Clin Cancer Res 2006, 12:6652-6662.

15. Letessier A, Sircoulomb F, Ginestier C, Cervera N, Monville F, Gelsi-Boyer V, Esterni B, Geneix J, Finetti P, Zemmour C, et al:: Frequency, prognostic impact, and subtype association of $8 p 12,8 q 24,11 q 13,12 p 13,17 q 12$, and $20 q 13$ amplifications in breast cancers. BMC Cancer 2006, 6:245.

16. Reis-Filho JS, Pinheiro C, Lambros MB, Milanezi F, Carvalho S, Savage K, Simpson PT, Jones C, Swift S, Mackay A, et al.: EGFR amplification and lack of activating mutations in metaplastic breast carcinomas. J Pathol 2006, 209:445-453.

17. Reis-Filho JS, Savage K, Lambros MB, James M, Steele D, Jones $\mathrm{RL}$, Dowsett M: Cyclin $\mathrm{D}_{1}$ protein overexpression and CCND1 amplification in breast carcinomas: an immunohistochemical and chromogenic in situ hybridisation analysis. Mod Pathol 2006, 19:999-1009.

18. Lambros MB, Simpson PT, Jones $C$, Natrajan R, Westbury $C$ Steele D, Savage K, Mackay A, Schmitt FC, Ashworth A, et al:: Unlocking pathology archives for molecular genetic studies: a reliable method to generate probes for chromogenic and fluorescent in situ hybridization. Lab Invest 2006, 86:398-408.

19. Tanner M, Gancberg D, Di Leo A, Larsimont D, Rouas G, Piccart MJ, Isola J: Chromogenic in situ hybridization: a practical alternative for fluorescence in situ hybridization to detect HER-2/ neu oncogene amplification in archival breast cancer samples. Am J Pathol 2000, 157:1467-1472.

20. Isola J, Tanner M: Chromogenic in situ hybridization in tumor pathology. Methods Mol Med 2004, 97:133-144.

21. Isola J, Tanner M, Forsyth A, Cooke TG, Watters AD, Bartlett JM: Interlaboratory comparison of HER-2 oncogene amplification as detected by chromogenic and fluorescence in situ hybridization. Clin Cancer Res 2004, 10:4793-4798.

22. Madjd Z, Pinder SE, Paish C, Ellis IO, Carmichael J, Durrant LG: Loss of CD59 expression in breast tumours correlates with poor survival. J Pathol 2003, 200:633-639.

23. Elston CW, Ellis IO: Pathological prognostic factors in breast cancer. I. The value of histological grade in breast cancer: experience from a large study with long-term follow-up. Histopathology 1991, 19:403-410.

24. Singletary SE, Connolly JL: Breast cancer staging: working with the sixth edition of the AJCC Cancer Staging Manual. CA Cancer J Clin 2006, 56:37-47.

25. Galea MH, Blamey RW, Elston CE, Ellis IO: The Nottingham Prognostic Index in primary breast cancer. Breast Cancer Res Treat 1992, 22:207-219.

26. Abd El-Rehim DM, Ball G, Pinder SE, Rakha EA, Paish C, Robertson JFR, MacMillan D, Blamey RW, Ellis IO: High throughput protein expression analysis using tissue microarray technology of a large well characterised series identifies biologically distinct classes of breast cancer confirming recent cDNA expression analyses. Int J Cancer 2005, 116:340-350. 
27. Abd El-Rehim DM, Pinder SE, Paish CE, Bell J, Blamey RW, Robertson JF, Nicholson RI, Ellis IO: Expression of luminal and basal cytokeratins in human breast carcinoma. J Pathol 2004, 203:661-671.

28. Nielsen TO, Hsu FD, Jensen $K$, Cheang M, Karaca G, Hu Z, Hernandez-Boussard T, Livasy C, Cowan D, Dressler L, et al.: Immunohistochemical and clinical characterization of the basal-like subtype of invasive breast carcinoma. Clin Cancer Res 2004, 10:5367-5374.

29. Bautista S, Theillet C: CCND1 and FGFR1 coamplification results in the colocalization of $11 q 13$ and $8 p 12$ sequences in breast tumor nuclei. Genes Chromosomes Cancer 1998, 22:268-277.

30. McLeskey SW, Ding IY, Lippman ME, Kern FG: MDA-MB-134 breast carcinoma cells overexpress fibroblast growth factor (FGF) receptors and are growth-inhibited by FGF ligands. Cancer Res 1994, 54:523-530.

31. Coumoul X, Deng CX: Roles of FGF receptors in mammalian development and congenital diseases. Birth Defects Res C Embryo Today 2003, 69:286-304.

32. Roumiantsev S, Krause DS, Neumann CA, Dimitri CA, Asiedu F, Cross NC, Van Etten RA: Distinct stem cell myeloproliferative/ T lymphoma syndromes induced by ZNF198-FGFR1 and BCRFGFR1 fusion genes from 8p11 translocations. Cancer Cell 2004, 5:287-298.

33. Chen J, Deangelo DJ, Kutok JL, Williams IR, Lee BH, Wadleigh M, Duclos N, Cohen S, Adelsperger J, Okabe R, et al:: PKC412 inhibits the zinc finger 198-fibroblast growth factor receptor 1 fusion tyrosine kinase and is active in treatment of stem cell myeloproliferative disorder. Proc Natl Acad Sci USA 2004, 101:14479-14484. 